\title{
Towards an Analytic of Violence: Foucault, Arendt \& Power
}

\author{
JACOB MAZE \\ Charles University, Czech Republic
}

\begin{abstract}
Violence is an often used but much less theoretically discussed word, even among Foucauldian scholars, with Johanna Oksala being a notable exception. However, she limits her definition of violence to physical forms. In this article, I seek to overcome the quandaries she poses for wide-ranging definitions of violence by incorporating Arendt's critique of violence into a Foucauldian paradigm. While some work, though not a great deal, has been done on comparing Arendt and Foucault, I highlight some points of commonality that makes Arendtian violence accessible to Foucauldian scholars that mostly rest on the concept of freedom. If power is productive to the extent that it provides the potential to act otherwise, Arendt, in many ways, situates violence as the prevention of this, similar to Foucault's account of domination. Violence and power are therefore cast in a symbiotic relationship, not limited to physicality, whereby power produces meaning as well as the ability to act and violence is projected as preventive; in such a scenario, the push for freedom can be positioned as a second-order normative claim.
\end{abstract}

Keywords: Arendt, Foucault, freedom, power, intersubjectivity, violence.

\section{INTRODUCTION}

In current research, academics are showing a tenacious willingness to engage with the topic of violence, whether it be in terrorism studies, social movement theory, sociology, feminism, literary studies or even philosophy. What is less common is an attempt to understand violence in its conceptual capacities, which would move us in a direction to more properly assess it in praxis. Foucauldian scholars have predominantly followed suit in this avoidance, ${ }^{1}$ with Johanna Oksala's book Foucault, Politics and Violence and

\footnotetext{
${ }^{1}$ For instance, see Idelber Avelar, The Letter of Violence: Essays on Narrative, Ethics, and Politics (2004); Michael Dillon and Andrew W. Neaal (ed.), Foucault on Politics, Security and War (2008); Elizabeth Frazer and Kimberly Hutchings, "Avowing Violence: Foucault and Derrida on Politics, Discourse and Meaning," Philosophy E Social Criticism 37:1 (2011).
} 
Frédéric Gros' article "Foucault, Penseur de la Violence?" being notable exceptions.2 In Oksala's text specifically, she aims to establish a framework for violence through the work of Michel Foucault, arguing for a narrow definition of "intentional bodily harm that reflects the sense in which violence is generally held to be categorically objectionable." 3 Oksala asserts that any broader definition not only inhibits scholarly research but also illegitimizes certain politically contested acts, such as protests or property damage, as well as "their political meaning or justification"; moreover, it risks making violence appear as a necessary component of the political. ${ }^{4}$ I use this article to provide, in contrast to Oksala, a wide-ranging understanding of violence that extends beyond "bodily harm" through a Foucauldian lens and explain how this, rather than reinforcing Oksala's predictions, supports a stronger position to comprehend historical manifestations of violence. To do so, I turn to Hannah Arendt, particularly her critique of violence.

The comparative research on Foucault and Arendt has been surprisingly scarce. Amy Allen has juxtaposed their theories of power, subjectivity and agency, ${ }^{5}$ while Frederick Dolan has outlined the similarities and differences between the two in their understanding of "sheer life" and the role of contemporary politics by looking at the notion of "biopower" and normalization in the wake of Modernity. ${ }^{6}$ In a similar vein, Jakub Franěk elucidated the commonality between Foucauldian biopower and Arendt's historical analysis in The Human Condition. ${ }^{7}$ A further honorable mention goes to Dana Villa, who has shown the compatibility between Arendt's and Foucault's differing understandings of power. ${ }^{8}$ Nevertheless, a deficit persists concerning the correlations of power in their respective theories, and there is a complete absence of any discussion on their conceptualizations of violence. Though often seen as a justified disinterest due to the ostensible interpretation that Foucauldian power is strategical ${ }^{9}$ while Arendtian power is communicative,$^{10}$ they both share a corresponding indebtedness to Martin Heidegger. ${ }^{11}$ The first section of this article, therefore, demonstrates that their respective theories are, in fact,

\footnotetext{
2 Johanna Oksala, Foucault, Politics, and Violence (2012); Frédéric Gros, "Foucault, Penseur de la Violence ?," Cités 50 (2012).

${ }^{3}$ Oksala, Foucault, Politics, and Violence, 9.

${ }^{4}$ Ibid.

5 Amy Allen, "Power, Subjectivity, and Agency: Between Arendt and Foucault," International Journal of Philosophical Studies 10:2 (2002).

${ }^{6}$ Frederick M. Dolan, "The Paradoxical Liberty of Bio-Power: Hannah Arendt and Michel Foucault on Modern Politics," Philosophy E Social Criticism 31:3 (2005).

7 Jakub Franěk, "Arendt and Foucault on Power, Resistance, and Critique," Acta Politologica 6:3 (2014).

${ }^{8}$ Dana R. Villa, "Postmodernism and the Public Sphere," The American Political Science Review 86:3 (1992).

${ }^{9}$ For instance, see Mark G. E. Kelly, The Political Philosophy of Michel Foucault (2012); Clare O'Farrell, Michel Foucault (2005); Jonathan Simons, Foucault and the Political (1995).

${ }^{10}$ For instance, see Margaret Canovan, Hannah Arendt: A Reinterpretation of Her Political Thought (1992); Karin A. Fry, Arendt: A Guide for the Perplexed (2009); Leo J. Penta, "Hannah Arendt: On Power," The Journal of Speculative Philosophy 10:3 (1996). However, as noted by Villa, Arendt's understanding of power should not be equated with a consensus-model, such as the kind that Habermas attributes to her. Oftentimes, Arendt explains power in agonistic terms, such as in The Human Condition and On Revolution (Villa, "Postmodernism and the Public Sphere," 717-718).

11 Dolan, "Paradoxical Liberty of Bio-Power"; Alan Milchman and Alan Rosenberg (ed.), Foucault and Heidegger: Critical Encounters (2003); Dana R. Villa, Arendt and Heidegger: The Fate of the Political (1996).
} 
reconcilable on a variety of points. With a theoretical grounding in freedom, they pose a degree of potential synthesis, which is the main reason I focus more on their similarities than their differences.

In the second section, I use this synthesis to sketch out Arendt's critique of violence that demarcates power (as productive) from violence (as preventive). This facilitates me in situating Arendt's critique into a Foucauldian framework in the final section. The core of this subsumption is freedom, or the ability to act otherwise, which is directly connected to the understanding of violence I put forward as the prevention of the potential to act otherwise, i.e., a determent of freedom. In the end, this arrangement is capacitated via the mapping out of historically contingent categories of violence dependent on power, thereby promoting a better method to the study of how violence is exercised in everyday life and beyond. In the conclusion, I return to Oksala's cautionary restrictions with the ambition not of diminishing the value of Oksala's work, which remains commendable and promising, but of presenting an ample alternative. Yet, as a caveat, it should be understood that I am working from a Foucauldian, not Arendtian, framework; if it appears that I am unfairly making more compromises on behalf of Arendt than Foucault, this is the reason.

\section{FOUCAULT, ARENDT \& POWER}

The backbone of Arendt and Foucault's theories is a confrontational approach to traditional notions of power that are wholly restrictive and repressive. Power has been established in conventional scholarly discourse as a top-down, substantive phenomenon, typically synonymous with violence, that represses individuals in a slew of manners. ${ }^{12}$ For Arendt, this credence roots power entirely in force, strength and violence, treating violence as "nothing more than the most flagrant manifestation of power"; however, these concepts are not equitable with power, and these scholars, "from Left to Right," misunderstand the relationships formed between individuals. ${ }^{13}$ If one continues this traditional line of thought, Arendt argues, it absolves individuals of any responsibility because accountability in the age of bureaucracy, or "rule by Nobody," means "there is no one left who could even be asked to answer for what is being done"; this is accomplished at the cost of freedom by removing all agency from power..$^{14}$ Likewise, Foucault sees traditional definitions as harmful since they fail to make "any connection between power and sex [or anything else] that is not negative," thereby overlooking the multitudinous outlets power actually takes, especially when providing capacities for action..$^{15}$ This "juridical" understanding of power neglects the possibility of altering mechanisms dangerously subjugating individuals by ignoring the many facets of power relations. As Foucault argues, "Nothing in society will be changed if mechanisms of power [...] are not also

\footnotetext{
${ }^{12}$ Allen, "Power, Subjectivity, and Agency," 132-136.

${ }^{13}$ Hannah Arendt, On Violence (1969), 35.

14 Ibid., 38-39.

${ }^{15}$ Michel Foucault, The History of Sexuality, Vol. 1: An Introduction [1976] (1990), 83.
} 
changed." 16 Taking this as our starting point, it becomes necessary to see how Arendt and Foucault situate power.

Allen argues that this is the primary parallel between the two writers, who, apart from this, take very different trajectories for dealing with power. ${ }^{17}$ One could even argue that these two thinkers, though using a similar vocabulary at times, were speaking of very different phenomena. Yet, this would overlook the similar attributes present in the thought of both philosophers, even if they do speak of different phenomena at times. Although they each have their own unique formulation of power, there is a severe overlap in their conceptualization of it, implying a significant overlap (though not always equality) in what they meant. For starters, both political philosophers build on consubstantial doctrines to reach their intellectual ends. For instance, their relational understanding of power, potentially stemming from Heidegger's influence, almost mirror one other. Rather than existing in any substantive, metasubjective or hermeneutical sense, Foucault asserts that power is formed through the relationships individuals form with one another: "Power exists only when it is put into action, even if, of course, it is integrated into a disparate field of possibilities brought to bear upon permanent structures." 18 Arendt likewise adheres to such a relational understanding of power, similarly stating that "all political institutions are manifestations and materializations of power; they petrify and decay as soon as the living power of the people ceases to uphold them." 19 For Foucault, power thereby functions as a conceptual substitute for the conglomeration of force relations strategically employed to (attempt to) control a situation. In more astute terms, power connotes "a relationship in which one person tries to control the conduct of the other [person]." ${ }^{20}$ Mark E. Kelly explains that these do not need to be nefarious relations; power instead captures the "how" and "why" of actions performed by subjects. ${ }^{21}$ An abusive husband is indeed one example, but so is a teacher trying to motivate a student or a rape prevention campaign.

Foucault further attests that force relations composing "power" are "both intentional and nonsubjective." 22 Richard Lynch notably criticized Foucault on this point because he sees the proposition as contradictory: if an act is intentional (exercised), it must also be subjective because it is enacted by a subject. ${ }^{23}$ However, this misses the depth of Foucault's argument, which he unravels a few sentences later: "There is no power that is exercised without a series of aims and objectives. But this does not mean that it results

16 Michel Foucault, "Body/Power" [1975], in Power/Knowledge: Selected Interviews and Other Writings, 19721977, ed. Colin Gordon (1980), 60.

${ }_{17}$ Allen, "Power, Subjectivity, and Agency."

${ }_{18}$ Michel Foucault, "The Subject and Power," in Michel Foucault: Beyond Structuralism and Hermeneutics (1982), 219.

${ }_{19}$ Arendt, On Violence, 41.

${ }_{20}$ Michel Foucault, “What Is Enlightenment?" [1984], in The Essential Foucault: Selections From Essential Works of Foucault, 1954-1984, ed. Paul Rabinow and Nikolas Rose (2003), 34.

${ }^{21}$ Kelly, Political Philosophy, 75.

${ }^{22}$ Foucault, History of Sexuality, 95.

${ }^{23}$ Richard Lynch, "Foucault's Theory of Power," in Michel Foucault: Key Concepts, ed. Dianna Taylor (2011), 23. 
from the choice or decision of an individual subject." 24 Subjects try to control the acts of others (or one's own) but lack the ultimate ability to foresee or govern the outcome, i.e., the subject is only ever partially autonomous. In an interview towards the end of his life, Foucault even adopts a vocabulary that reflects Arendt's by stressing that some particular end can be affected by other subjects: In this case, unexpected acts "are results that are adapted to different uses, and these uses are rationalized - organized, in any case in terms of new ends." ${ }^{25}$ To put it more simply, strategies oftentimes backfire. Foucault's work on the prison excellently captures this point in that the ambition to curb illegal activity not only contributed to a new manner of legal transgressions but also the notion of criminality itself. ${ }^{26}$ Through all of these conflicting strategies, a series of fluctuating, non-autonomous and circulating relationships form networks and coalesce, eventually producing meaning, or a "historical construct" ${ }^{27}$ : "All of this means that power, when it is exercised through these subtle mechanisms, cannot but evolve, organize and put into circulation a knowledge." ${ }^{28}$ Consequently, "Far from preventing knowledge, power produces it." 29

As networks of relations develop, they make the subject's actions and its world intelligible to it. Yet, it is not only that the world becomes intelligible to the subject, but it is also what enables a subject to act in the first place, which may seem like a rather odd notion: "The individual is an effect of power, and at the same time, or precisely to the extent to which it is that effect, it is the element of its articulation. The individual which power has constituted is at the same time its vehicle." ${ }^{\prime 0}$ A notable illustration that comes into play at this point is the identity of minority communities or social movements; one can only make sense of the Black community or feminism through race and sexuality respectively. Without either of the latter two concepts, the previous two would, quite literally, be inconceivable (although could exist in a very different form along different social lines). This social backdrop, which is "the viewpoint which permits one to understand [power's] exercise," is termed the "condition of possibility," or that which allows certain identifications to make sense and enables one to act. ${ }^{31}$ While the condition of possibility does include the possibility to act, and this will be important when discussing Arendt, it is not restricted to action; it encompasses the possibilities that can be conceived at any given time as well as the space in which acts (and speech) are carried out.

\footnotetext{
${ }^{24}$ Foucault, History of Sexuality, 95.

${ }^{25}$ Michel Foucault, "What is Called 'Punishing?'” [1984], in Essential Works of Foucault 1954-1984, Volume 3: Power, ed. James D. Faubion (2001), 386.

${ }^{26}$ Michel Foucault, Discipline E Punish: The Birth of the Prison [1975] (1995).

${ }^{27}$ Foucault, History of Sexuality, 105.

${ }^{28}$ Michel Foucault, "Two Lectures" [1976], in Critique and Power: Recasting the Foucault/Habermas Debate, ed. Michael Kelly (1994), 40.

${ }^{29}$ Ibid., 28.

${ }^{30}$ Ibid., 36.

${ }^{31}$ Foucault, History of Sexuality, 93. Moreover, in Foucault's writings, the "condition of possibility," the "historical a priori" and the "field of possibilities" may contain subtle differences, but I refer to them as synonymous in this article.
} 
Moreover, one can never own power because it only ever exists in its exercise; it "is not something that is acquired, seized, or shared," but one can solely exercise power "from innumerable points in the interplay of nonegalitarian and mobile relations." ${ }^{32}$ If meaning is constructed through such unequal force relations, the subject can consequently only come to exist, and understand itself, through power. How could subjects form a Black solidarity movement if they were never constituted as Black in the first place? Therefore, power can be seen as enabling as it is limiting, for only through power relations do our capacities for action arise. This rejects the negative, predeterminative picture that has been attributed to Foucault, ${ }^{33}$ yet his strategy-heavy understanding of power is what has traditionally separated him from Arendt.

Like Foucault, Arendt conceives of power not in any substantive sense but as being created through its exercise, or the bonds that are created through plurality and without which it would cease to exist. She writes, "Power springs up between men when they act together and vanishes the moment they disperse." ${ }_{34}$ Appearing where individuals form connections with one another, it gives rise to "the potential space of appearance between acting and speaking men," or, in other words, meaning. ${ }^{35}$ The "space of appearance" is the surrogate of Foucault's condition of possibility and, according to Villa, is the "minimum agreement in background judgments and practices" required for collective or intersubjective action/speech. ${ }^{36}$ The relationships that form between individuals is defined as the "in-between," and only through this in-between, "which lies between people and therefore can relate and bind them together," can subjects understand the world. ${ }^{37}$ Yet, with great closeness to Foucault, the space of appearance is not limited to making the world intelligible but also makes action possible. As Arendt wrote in one of her final works:

To the invisible that manifests itself to thinking there corresponds a human faculty that is not only, like other faculties, invisible so long as it is latent, a mere potentiality, but remains non-manifest in full actuality.... Neither laboring nor fabrication requires display of the activity itself; only action and speaking need a space of appearance - as well as people who see and hear - in order to be actualized at all. But none of these activities is invisible. ${ }^{38}$

In this way, power is very real, perhaps the most "real," component of existence for Foucault and Arendt (even if Foucault would disagree that it is a "human faculty"). The latter claims, "For all its intangibility, this in-between is no less real than the world of things we visibly have in common. We call this reality the 'web' of human relationships,

\footnotetext{
32 Ibid., 94.

${ }^{33}$ For example, see Jean Baudrillard, Forget Foucault [1977] (2007); Toril Moi, "Power, Sex and Subjectivity:

Feminist Reflections on Foucault," Paragraph 5 (1985): 95-102.

${ }^{34}$ Hannah Arendt, The Human Condition [1958] (1998), 200.

${ }^{35}$ Ibid.

${ }^{36}$ Villa, Arendt and Heidegger, 34. Also see Allen, "Power, Subjectivity, and Agency," 138-139.

37 Arendt, Human Condition, 182.

${ }^{38}$ Hannah Arendt, The Life of the Mind [1971] (1978), 72.
} 
indicating by the metaphor its somewhat intangible quality." ${ }^{39}$ Tangibility can only make sense to us through the space of appearance, the in-betweenness, offered by power, "even if their content is exclusively 'objective,' concerned with the matters of the world of things in which men move." 40 Foucault goes further, nonetheless, in that the dichotomy of tangibility-intangibility is rejected altogether: "Nothing is more material, physical, corporal than the exercise of power." 41

Arendt moreover affirms that power cannot be owned but only exercised, writing, "Power cannot be stored up and kept in reserve for emergencies, like the instruments of violence, but exists only in its actualization. Where power is not actualized, it passes away." 42 Margaret Canovan emphasizes that Arendtian power is only conceivable as action, in its performance, which in turn constructs the world. ${ }^{33}$ What Arendt is insinuating here is that the world comes to appear, and can only come to appear, through intersubjective actions; inversely, it is this very process of acting that constitutes the subjects to themselves and others. Thus, Foucault's logic of subjective constitution is also applied by Arendt: "The invisible actor behind the scenes is an invention arising from a mental perplexity but corresponding to no real experience." ${ }^{44}$ What this entails is that, for Arendt and Foucault, power is generative and productive, producing the condition of possibility/space of appearance as well as the subject. It makes communication between subjects and action in general possible.

Yet, many theorists argue that Foucault, while attempting to smother any normative claims, differs from Arendt who declares power to be inherently good. ${ }^{45}$ There is unarguably some truth to this, but one must be careful not to misconstrue Arendt's project. Franěk explains, "Arendt's thought is primarily critical, rather than normative." 46 Unlike freedom, power is a descriptive term for Arendt and part of the human condition, as she herself argues: "Power preserves the public realm and the space of appearance, and as such it is also the lifeblood of the human artifice." 47 It is not that one would be better off in a social system with more or less power, but merely that one could not make sense of the world at all without it. For instance, she explains in On Violence that "no government exclusively based on the means of violence has ever existed. Even the totalitarian ruler,

\footnotetext{
${ }^{39}$ Arendt, Human Condition, 183.

${ }^{40}$ Ibid., 182.

${ }^{41}$ Foucault, "Body/Power," 58. Foucault argued for a time for a division between discursive and nondiscursive (Michel Foucault, The Archeology of Knowledge and The Discourse on Language [1969] (2010), 162164). Nevertheless, he later explains that this was allegedly not meant to be taken literally and that such a division is not sustainable nor of great importance to his theory of power (Michel Foucault, "Confessions of the Flesh [1977]," in Power/Knowledge: Selected Interviews \& Other Writings 1972-77, ed. Colin Gordon (1980), 197-198).

42 Arendt, Human Condition, 200.

${ }^{43}$ Canovan, Hannah Arendt, 95.

${ }^{44}$ Arendt, Human Condition, 185.

45 Canovan, Hannah Arendt; Jürgen Habermas, "Hannah Arendt's Communications Concept of Power" [1977], in Hannah Arendt: Critical Essays, ed. Lewis P. Hinchman and Sandra K. Hinchman (1994).

${ }^{46}$ Franěk, "Arendt and Foucault," 305.

47 Arendt, Human Condition, 204.
} 
whose chief instrument of rule is torture, needs a power basis." 48 In other words, there must be a space where the totalitarian ruler, in this scenario, is able to communicate and interact with her/his subjects, and they must have a method for understanding one another. Though power is what allows individuals to communicate, this does not make power "good."

Even if this is the case, scholars have additionally argued that that there is a significant contrast between Foucault's strategy-based account of power and Arendtian power, which is an end-in-itself and thus not instrumental. According to their line of reasoning, Arendt's power is solely based on principles of communication. ${ }^{49}$ However, this goes against what Arendt herself advocated. Power allows subjects to communicate, but it is by no means limited to this since action itself would cease to make sense without it. While discussing totalitarianism, Arendt argues that it "destroys the one essential prerequisite of all freedom which is simply the capacity of motion which cannot exist without space." 50 The product of power - the space of appearance - is what transcends individuals. Power's productive component precedes and outlasts the subject, making it an end-in-itself:

This, of course, is not to deny that governments pursue policies and employ their power to achieve prescribed goals. But the power structure itself precedes and outlasts all aims, so that power, far from being the means to an end, is actually the very condition enabling a group of people to think and act in terms of the means-end category. ${ }^{51}$

Power can be exercised instrumentally, but it can never exist instrumentally, meaning that she falls much closer to Foucault than others have acknowledged, especially considering Foucault's placement of power in "means-ends" terms earlier. In more astute terms, power exists through its exercise (Foucault) or action (Arendt) such that it produces and is continually reproduced as well as reinforced by the very subject it constitutes; these subjects themselves instrumentally use the conditions of possibility (Foucault) or the space of appearance (Arendt) to pursue various subjective strategies (Foucault) or ends (Arendt); however, since they are within a network amidst other acting subjects, they never have the capacity to wholly control the outcome nor the interpretation of their actions. The accumulation of this is a structure that transcends the various individual ambitions but which, at the same time, gives meaning to the world on which individual subjects rely; thus, power exists, but not in any subjectively instrumental fashion.

This demonstrates a strong correlation between Arendt and Foucault, yet it still cannot be said that their theories are equivalent. Arendt is immensely invested in understanding the concept of power in a cut-and-dry demeanor, but Foucault is apt to openly embrace the ambiguities and obscurities that arise in such an investigation. More sub-

\footnotetext{
48 Arendt, On Violence, 50.

${ }^{49}$ For examples of this argument, see Seyla Benhabib, "Hannah Arendt and the Redemptive Power of Narrative," in Hannah Arendt: Critical Essays, eds. Lewis P. Hinchman and Sandra K. Hinchman (1994); Habermas, "Hannah Arendt's Communications."

${ }^{50}$ My emphasis, Hannah Arendt, The Origins of Totalitarianism [1951] (1979), 466.

${ }^{51}$ Arendt, On Violence, 51.
} 
stantially, Arendt scouts out the communicative qualities of power whereas Foucault avidly digs through archival material to highlight the more subtle mechanisms contingently instilled through power; Arendt is assuredly sympathetic to this cause in light of her work in The Human Condition and The Origins of Totalitarianism, yet even here her focus is more on the human condition than specific practices. Her analyses aimed to uncover trans-historical phenomena rather than spatio-temporally confined experiences, which was the aim of Foucault. Nevertheless, though discrepancies do exist between them, this insight presents a more manageable divide than previously assumed.

\section{ARENDT, VIOLENCE AND SPONTANEITY}

The best way to bridge this divide is by investigating the self-attested grounding of both their philosophies: freedom. The subject not only exercises power but is exercised on by power. This is not to be confused with determinism as subjects "are always conditioned beings," but never wholly conditioned. ${ }^{52}$ Later in her life, Arendt even asserted in more direct terms that "the opposite of necessity is not contingency or accident but freedom." 53 Foucault declares that it is the exercise of power on the subject that enables it to act freely in the first place: "The individual is in fact a power-effect, and at the same time, and to the extent that he is a power-effect, the individual is a relay." ${ }^{44}$ In a familiar tone, then, Arendt asserts that "if men wish to be free, it is precisely sovereignty they must renounce." ${ }^{55}$ Freedom and conditionality are closely related, for one cannot exist without the other. Through this dichotomous relationship, agents emerge as free to act otherwise, i.e., have potentiality: "Because the actor always moves among and in relation to other acting beings, he is never merely a 'doer' but always at the same time a sufferer. To do and to suffer are like opposite sides of the same coin." 56 The key to freedom, then, is the possibility to act otherwise, and power rests on this potentiality, or rather it is what makes potentiality possible, just as potentiality is contingent upon power, which Foucault stressed: "In power relations there is necessarily the possibility of resistance because if there were no possibility of resistance...there would be no power relations at all." ${ }^{57}$ To this end, power does not occur beyond but between subjects. ${ }^{58}$

\footnotetext{
${ }^{52}$ Arendt, Human Condition, 9.

${ }^{53}$ Arendt, Life of the Mind, 60.

${ }^{54}$ Michel Foucault, "Society Must Be Defended": Lectures at the Collège de France, 1975-1976 [1997] (2003), 30. While Allen declares that the possibility of solidarity existing in Foucault's thought is impossible due to the nature of his understanding of power (Allen, "Power, Subjectivity, and Agency," 143), it is precisely that which makes it possible. Only after being constituted as a woman (subjection) can one then form solidarity movements based on that identity.

${ }^{55}$ Hannah Arendt, “What Is Freedom?" [1961], in The Portable Hannah Arendt, ed. Peter Baehr (2000), 455.

${ }^{56}$ Arendt, Human Condition, 190.

${ }^{57}$ Michel Foucault, "The Ethics of the Concern for Self as a Practice of Freedom" [1984], in Essential Works of Foucault 1954-1984, Volume 1: Ethics, Subjectivity and Truth, ed. Paul Rabinow (1997), 292.

${ }^{58}$ Though Foucault does discuss intra-subjective relationships in his later writing, this still involves forming a relationship with oneself. Even in this instance, the role of power functions through a relationship with two sides.
} 
Given freedom's centrality to both philosophers, it is surprising more has not been done on this. For Foucault, the retainable component of the Enlightenment is precisely this desire "to imagine [the world] otherwise than it is, and to transform it not by destroying it but by grasping it in what it is." ${ }^{59}$ The value of this potentiality is resistance, which contextualizes his notoriously cited claim, "Where there is power, there is resistance." 60 The capabilities power offers, which go along with all forms of restriction, persuasion and coercion, enable the subject to act unexpectedly (or "spontaneously" in Arendtian parlance) "by taking such discourses literally, and thereby turning them around." ${ }^{61}$ Power is precisely the promise of potentiality, even for Arendt: "Freedom, as we would say today, was experienced in spontaneity." ${ }^{2}$ In this way, "Beginning [or spontaneity]...is the supreme capacity of man; politically, it is identical with man's freedom." ${ }_{63}$ With a similar philosophical grounding in place, the question that now arises in the context of this article is how violence, read through Arendt, can be reincorporated into a Foucauldian framework.

For Arendt, the core difference between power and violence is that violence is always employed instrumentally to achieve an objective, whereas power is an end-in-itself. ${ }^{64}$ Though power is exercised, it does not reduce to any teleological basis like in the Hegelian and Marxist traditions, which would present some extent of predeterminism - sovereignty - and therefore relinquish freedom. ${ }^{65}$ By submitting to an overdetermination of progress, "We are assured that nothing altogether new and totally unexpected can happen, nothing but the 'necessary' results of what we already know." ${ }_{66}$ Therefore, she carefully delineates between an instrumental model of violence and a relational, nonautonomous power, even expressing shock that "violence has been singled out so seldom for special consideration" in light of the role it plays in political life.67 The danger of violence's instrumental existence, i.e., involved in the oscillation of means-ends, "has always been that the end is in danger of being over-whelmed by the means which it justifies." 68 This framing allows Arendt to argue for the inherent subjective aims that taint violence while power produces the space of appearance by which, though capable of being employed instrumentally, potentiality has the capacity to prosper.

One of the substratal qualities of power, therefore, is its ability to generate political existence. Not only is there no underlying reason for it to exist, but by the same token it would be impossible for it to be otherwise. Sans meaning, humans life would be "literally dead to the world; it has ceased to be a human life because it is no longer lived among

\footnotetext{
${ }^{59}$ Foucault, "What Is Enlightenment?" 50.

${ }^{60}$ Foucault, History of Sexuality, 95.

${ }^{61}$ Michel Foucault, "Power and Sex" [1977], in Michel Foucault: Politics, Philosophy, Culture, Interviews and Other Writings 1977-1984, ed. Lawrence D. Kritzman (1990), 115.

62 Arendt, "What Is Freedom?," 456.

${ }_{63}$ Arendt, Origins of Totalitarianism, 479.

${ }^{64}$ Arendt, On Violence, 46.

${ }^{65}$ Canovan, Hannah Arendt, 84.

${ }^{66}$ Arendt, On Violence, 28.

${ }^{67}$ Ibid., 8.

${ }^{68}$ Ibid., 4.
} 
men." ${ }^{9}$ The minute an individual acts in the company of others, power spawns as the space of appearance. ${ }^{70}$ In other words, power makes subjects - and the world in which they inhabit - intelligible to one another and enables communication: "Power preserves the public realm and the space of appearance... which, unless it is the scene of action and speech, of the web of human affairs and relationships and the stories engendered by them, lacks its ultimate raison d'etre." ${ }^{71}$ Put simply, power is pluralistic, working through - and between - individuals. What is more, Arendt draws a direct connection between politics and freedom as well, also positioning it as the raison d'être of politics: "Without [freedom], political life as such would be meaningless. The raison d'être of politics is freedom, and its field of experience is action." ${ }^{72}$ By contrast, violence is individualistic. Certainly violence can be used collectively, hence "collective violence," but it is always a particular deployment of violence. It fails to constitute the in-betweenness of individuals as power does; it merely takes place there. Arendt explains, "The extreme form of power is All against One, the extreme form of violence is One against All. And this latter is

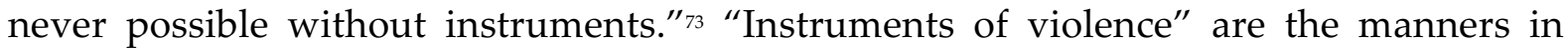
which violence exerts itself, and, unlike power, they can be owned. However, uncovering what these instruments are presents a bit of a quandary in Arendt's writing, and the question arises as to whether she herself invariably and consistently employed "instruments of violence" throughout her work.

Typically, one would assume material tools: guns, bombs, prisons, military mechanisms, terrorist attacks or Molotov cocktails. If power depends on pluralism, violence seeks compliance through instruments amplifying one's strength. ${ }^{74}$ However, are physical objects the only way to go about this? Arendt explains the situation as follows:

Violence, we must remember, does not depend on numbers or opinions, but on implements, and the implements of violence, as I mentioned before, like all other tools, increase and multiply human strength. Those who oppose violence with mere power will soon find that they are confronted not by men but by men's artifacts, whose inhumanity and destructive effectiveness increase in proportion to the distance separating the opponents. Violence can always destroy power; out of the barrel of a gun grows the most effective command, resulting in the most instant and perfect obedience. What never can grow out of it is power. ${ }^{75}$

Power exists through acts, but it is not reducible to them. In contradistinction, violence only comes to be through acts, "implements," with no trans-subjective components. It relies on material instruments, not the generation of the space of appearance, which usually causes violence to be perceived as its physical manifestations. ${ }^{76}$

\footnotetext{
${ }^{69}$ Arendt, Human Condition, 176.

${ }^{70}$ Villa, Arendt and Heidegger, 34.

${ }^{71}$ Arendt, Human Condition, 204.

${ }^{72}$ Arendt, "What is Freedom?," 440.

${ }^{73}$ Arendt, On Violence, 42.

74 Ibid., 46.

75 Ibid., 53.

${ }^{76}$ For example, Penta, "Hannah Arendt," 211.
} 
In light of this, Arendt's differentiation of violence with other concepts does not help one solidly claim that violence is physical or non-physical. In this section of the text, she distinguishes violence from "force" (the energy released by natural or social movements), "strength" (an individual person's or object's capabilities in relation to another person or thing), "authority" (one's absolute and unquestionable submission to someone or something) and "power." 77 In her article "Truth and Politics," violence is shown to be, if not identical, directly related to compulsion: "Without the help of violence...truth would then owe its prevalence not to its own compelling quality but to the agreement of the many." 78 Moreover, in The Life of the Mind, Arendt appears to differentiate between "violence" (which is physical) and "force" (which is nonphysical). ${ }^{79}$

One problem in reading physicality into violence (regardless of whether Arendt intended this) is that it risks misinterpreting the stakes at play for Arendt (even if she herself did not consistently frame violence's relation to physical altercations in between her works), who is discussing functions rather than methods. Though there are times when instruments of violence are meant in a rather material tone, ${ }^{80}$ this does not hold true for all her discussions of violence. ${ }^{81}$ At the same time, there is a distinction to be made between instruments of violence and violence as a concept, with the prior merely being the manner in which the latter is achieved. Finally, there is the question of whether Arendt's occasional leanings towards physical connotations are sustainable within her overarching understanding of violence. Physical violence is the terminal form violence takes, especially if violence is always rationalized (or justified but not legitimate, as Arendt would argue), meaning that it always has a reason - no matter how distasteful we may view it - for being done. ${ }^{82}$ Considering that she sees the opposite of power as violence, even to the extent that "non-violent power is redundant," it does not seem like it is reducible to physical altercations just as power is not reducible to non-physical interactions. ${ }^{83}$ I think her account of Terror sheds some light on this while also opening the doors to a wider application of her theory of violence that is more consistent than perhaps even she herself was.

Terror occurs when all power has been blocked, meaning the possibility for spontaneous action has been entirely foreclosed: "Terror is not the same as violence; it is, rather, the form of government that comes into being when violence, having destroyed all power, does not abdicate but, on the contrary, remains in full control." 84 The key to understanding Arendtian violence is this "full control": "Totalitarian domination, however, aims at abolishing freedom, even at eliminating human spontaneity in general, and

\footnotetext{
77 Arendt, On Violence, 44-46.

${ }^{78}$ Hannah Arendt, “Truth and Politics" [1967], in The Portable Hannah Arendt, ed. Peter Baehr (2000), 560.

${ }^{79}$ Arendt, Life of the Mind, 60.

${ }^{80}$ For instance, see Arendt, Human Condition, 180; On Violence, 4, 46.

${ }^{81}$ For instance, see Arendt, Human Condition, 179, 228; On Violence, 18, 50-51, 79; “What Is Freedom?," 455.

82 Arendt, On Violence, 66.

83 Ibid., 56.

84 Ibid., 55.
} 
by no means at a restriction of freedom no matter how tyrannical." ${ }^{85}$ If power is essentially linked to potentiality, violence would be when that potentiality to act otherwise is ultimately destroyed (or at least lessened), which is further resonated by Foucault: "Where the determining factors saturate the whole there is no relationship of power; slavery is not a power relationship when man is in chains." ${ }_{86}$ Pure violence, or Terror, is the absence of potentiality (power), and to limit violence to physical perpetration ignores the value of Arendt's observation: "If it were true that sovereignty and freedom are the same, then indeed no man could be free, because sovereignty, the ideal of uncompromising self-sufficiency and mastership, is contradictory to the very condition of plurality." 87

In Origins of Totalitarianism, she even claims that "freedom as an inner capacity of man is identical with the capacity to begin, just as freedom as a political reality is identical with a space of movement between men." 88 Situations in which the ability to act otherwise, or freedom, is annexed is a direct affront to both the meaningful world and the subject's very existence, and violence assumes the role in Arendtian philosophy of diminishing one's ability to act otherwise, in both physical and non-physical terms. In other words, the greater the ratio of violence-to-power is weighted towards violence, the more determinative the situation is. In Arendt's constructivist tone, to which violence and power are not natural but constructed by humans, how the body is defined, and by consequence the limits of physicality, is constantly contested. ${ }^{89}$ Given the amount of discourse on the body in feminist literature at present, making this distinction does not appear to be sustainable for Arendt. The inability to properly discern between the physical and the non-physical in her account of the space of appearances and what is real (discussed via "tangibility" in the previous section) further demonstrates that Arendt's intermittent account of instruments as material is not entirely consistent with her understanding of violence, even if she adheres to this view at times (for instance, she refers to the army and police as instruments of violence).${ }^{90}$

To resolve this issue, it is necessary to get to the root of Arendt's concern with power. The significant difference between power and violence is the potentiality to act otherwise: power permits it and violence prevents it. These are not two competing forces but corresponding ones that are, to steal Arendt's phrase, two sides of the same coin; they are by no means mutually exclusive: "Power and violence, though they are distinct phenomena, usually appear together. Wherever they are combined, power, we have found, is the primary and predominant factor." "91 Arendt's claim that violence can destroy power but not produce it makes sense once violence is installed as the prevention of potential. It is also worth noting that Arendt is not against violence itself: "Nothing could ever

\footnotetext{
85 Arendt, Origins of Totalitarianism, 405.

86 Foucault, "Subject and Power," 221.

${ }^{87}$ Arendt, Human Condition, 234.

${ }^{88}$ Arendt, Origins of Totalitarianism, 466.

${ }^{89}$ Arendt, On Violence, 82.

${ }^{90}$ Arendt, Origins of Totalitarianism, xxxvi, 136, 379.

${ }_{91}$ Arendt, On Violence, 52.
} 
happen if reality did not kill, by definition, all the other potentialities originally inherent in any given situation." 92 On many occasions, she even advocated it, such as her desire to have a Jewish Army established in the midst of WWII. ${ }^{33}$ In the absence of meaning, violence becomes useless and incomprehensible. Still, though violence is aimed at restriction, it is not always repressive. It takes many forms, e.g., coercion, compulsion, incentivization, normalization or monetary persuasion. It can be personal or institutional. For instance, when Turkey experienced the Gezi protests in 2013, a conglomeration of groups with different motives took to the streets together in an attempt to stifle the increasingly authoritarian model of government; in doing so, their actions where aimed at preventing this form of governance (its spontaneity) in various ways, from Molotov cocktails to sit-ins, making the protestors physically or institutionally violent (this is not considering the government's response to the protest, which would be considered preventive, and thereby violent, as well). On the other hand, a space where these different ideological perspectives could engage in a dialogue arose, producing a rather unique space of appearance, which would be considered power. It furthermore would not be plausible to reduce this to a mere dichotomy, as often times power and violence work together, to varying degrees, forming and blocking off competing strategies and intentions in a non-linear progression and with complex and interconnecting methods.

Yet, in my expansion of Arendtian violence, there nevertheless persists the dilemma of why power is non-instrumental but violence is. Allen correctly notes that power escapes any instrumental projects by being that which constructs a meaningful world through intersubjective relationships, the in-between. ${ }^{44}$ This relies on acts being nonsovereign with an uncontrollable component. Logically, it would seem that violence follows the same pattern. Arendt writes, "To resort to violence when confronted with outrageous events or conditions is enormously tempting because of its inherent immediacy and swiftness." ${ }^{95}$ Yet, in actuality, acts of violence are not aimed at producing anything but are rather engrained in the prevention of another strategy, be it hegemonic or periphery; though this is often done to secure a path for the subject's own strategy to proceed, this is the side of the issue rooted in power. In the example of the Gezi protests, the protestors did not merely want the current government to resign, but they also wanted a more democratic, inclusive one to take its place. Thus, relations of violence play into power (and vice versa), but violence itself is not productive, and thereby instrumental and not generative in nature.

Such a framing does not imply an irrational burst of contempt when violence occurs but a strategy, even if sometimes ill-founded, aimed at preventing, or harming, some form of potentiality. Therefore, violence is engrained in meaning and intersubjectivity violence cannot come from an isolated individual - and over time instruments of vio-

\footnotetext{
92 My emphasis, Arendt, “Truth and Politics," 557.

${ }^{93}$ Hannah Arendt, “The Jewish War That Isn't Happening: Articles from Aufbau, October 1941-November 1943," in The Jewish Writings, ed. Jerome Kohn and Ron H. Feldman (2007); for more on the inability to control violence, see Arendt, On Violence, 52.

${ }_{94}$ Allen, "Power, Subjectivity, and Agency," 137-138.

${ }_{95}$ Arendt, On Violence, 63; see also 63-69 for her discussion on rage, rationality and violence.
} 
lence are formed; still, violence itself is never owned by anyone, and this is where a distinction should be made between the instruments of violence and the concept of violence. A gun is an instrument of violence, and surely one can own a gun. Yet, based on the account of the physical and the non-physical given above, it would seem there are many instruments (of violence) that in fact cannot be owned. A police force may break up a protest, but the police are not owned by the state; it is merely one outlet that the state uses to exercise violence. One could make an even stronger case when considering protest movements, especially if militant in nature. Though this position on instruments of violence appears to be a bit more intricate and perplexing, it should be clear that violence is exercised rather than owned.

Clearly, some concessions from Arendt on this point are needed. The indispensable productiveness of power remains, and violence is seen as only interacting with the world, not creating it. Certainly, violence would shape and influence the world, working to prevent certain manifestations in order to enable others, but it functions at the level of what already exists. In order for violence to be exercised at any nexus of power relations, they would have to be created first; for example, in order for protestors to attack an authoritarian regime, that system of government needs to have been produced. For this reason, power is still perceived as "the primary and predominant factor" to violence. In this way, violence can only spawn from what has already been produced, though it frequently works to prevent certain phenomenon from entering the space of appearance, at least hegemonically speaking.

In the larger picture, violence would need categories of power to justify itself. One of the reasons Arendt was so consistently cautious of advocating instances of violence, though not reluctant to do so, was this justification process, which leads to acts the initiator can never fully control. Even in what one would consider a "justified" case of violence, it can very easily get out of hand:

Violence, being instrumental in nature, is rational to the extent that it is effective in reaching the end that must justify it. And since when we act we never know with any certainty the eventual consequences of what we are doing, violence can remain rational only if it pursues short-term goals. ${ }^{96}$

While Arendt is trying to elicit a difference between justified and unjustified violence, her main point is rather the fact that one cannot control the ends; thus, the longer the means continue, the more chance there is for things to get out of hand: Violence's "justification loses in plausibility the farther its intended end recedes into the future. No one questions the use of violence in self-defense, because the danger is not only clear but also present, and the end justifying the means is immediate." ${ }^{97}$ This takes us to the difficult question of whether violence is good (desired) or bad (undesired). If we start to look at categories of violence, meaning the bases from which violent acts justify themselves, it would be immensely more helpful to us. It would allow us to understand violence (a)

${ }^{96}$ Ibid., 79.

97 Ibid., 52. 
descriptively and (b) not in any physical/non-physical binary but in terms of processes of rationalization. Transposing Arendt's critique of violence onto a Foucauldian paradigm permits just this.

\section{FOUCAULT, VIOLENCE AND GENEALOGY}

For many philosophers, the inability to accept Foucault's position resulted from how he dealt with, or rather willingly did not deal with, normative judgments but instead bracketed them completely. ${ }^{98}$ Foucault avoided making normative claims for the sheer fact that it would undermine his genealogical domains of analysis. Only by removing the universal normative foundations along with any teleological hardwiring was he able to ascertain his descriptive genealogy. While explaining moral value may seem important for historians, Foucault witnessed this as a problem within the field of history that wished to "confirm our belief that the present rests upon profound intentions and immutable necessities" when in actuality it had been constructed from "countless lost events, without a landmark or a point of reference," a claim with which Arendt would no doubt be quite in agreement. ${ }^{9}$ Reassembling the trajectories of construction for power's condition of possibility - "in the most unpromising places, in what we tend to feel is without history - in sentiments, love, conscience, instincts"100 - we can better understand why we act in the ways we do. Notably, Foucault's stance towards politics in this respect veers from Arendt's, who sought to strictly separate the public from the private: "The role of political power... [is] to reinscribe [its struggles] in social institutions, in economic inequalities, in language, in the bodies themselves of each and every one of us. " ${ }^{101}$ In contrast to Arendt, Foucault wishes to show how these mundane attributes and overlooked relationships are consistently drawn into and constitutive of the political landscape, yet they often go unnoticed.

Though we may map out historical developments in this way, or the study of "historical ontology" as Oksala argues, ${ }^{102}$ we come no closer to achieving wholly autonomous free will, yet it does help in "disentangling this indefinite knot" of the dangers of our particular networks of power relations. ${ }^{103}$ Foucault asserted, "We have to know the historical conditions which motivate our conceptualization. We need a historical awareness of our present circumstances." ${ }^{104}$ Nonetheless, the account of power relations given thus far, even limited to those phenomena of which we are most assured, does not help us in

\footnotetext{
${ }^{98}$ For instance, see Nancy Fraser, “Michel Foucault: A 'Young Conservative?”" [1985], in Critique and Power: Recasting the Foucault/Habermas Debate, ed. Michael Kelly (1994); Jürgen Habermas, The Philosophical Discourse of Modernity: Twelve Lectures [1985] (1990).

${ }^{99}$ Michel Foucault, "Nietzsche, Genealogy, History" [1971], in The Essential Foucault: Selections From Essential Works of Foucault, 1954-1984, ed. Paul Rabinow and Nikolas Rose (2003), 361.

${ }^{100}$ Ibid., 351.

${ }^{101}$ Foucault, "Two Lectures," 29.

${ }^{102}$ Oksala, Foucault, Politics, and Violence, 23-24.

${ }_{103}$ Michel Foucault, "The History of Sexuality" [1977], in Power/Knowledge: Selected Interviews and Other Writings, 1972-1977, ed. Colin Gordon (1980), 60.

${ }^{104}$ Foucault, "Subject and Power," 209.
} 
discerning particular concentrations of power (nor violence) in praxis but works exclusively on a theoretical level. What Foucault projected, therefore, was a genealogy of dispositifs (mechanisms of power; apparatus), those consolidations of reinforced power relations most resistant to change like sexuality, race or the state: "I'm starting off from an apparatus [dispositif] of sexuality, a fundamental historical given which must be an indispensable point of departure for us." ${ }^{105}$ It is necessary to pinpoint the historical site at which a dispositif, in this case sexuality, became something possible to speak of and exercise; therefore, one must hone in on "the subjected knowledges which were thus released [and] would be brought into play." ${ }^{106}$ For instance, one could look at nationalism and the site at which it became possible not only to belong to a nation, but how individuals as well as Nation-States exercised programs of national solidarity and constructed methods for national inclusion (and exclusion), which was a project pursued by both Arendt and Foucault to varying degrees. ${ }^{107}$ In doing so, an investigator would be required to ask, "If power is exercised, what sort of exercise does it involve? In what does it consist? What is its mechanism?" ${ }_{108}$ Before we see how violence fits into this paradigm, a distinction must be made between genealogy, as explained here, and Foucault's "analytic of power."

Foucauldian genealogy outlines specific concentrations of power and does not make claims about power in general. In contrast, his analytic of power more closely aligns itself with the philosophical tradition of critique. ${ }^{109}$ He was overtly cautious of putting forward any general "theory" of power and instead worked on outlining the existential limits that would allot an investigation into power on more circumstantial grounds:

If one tries to erect a theory of power one will be obliged to view it as emerging at a given place and time and hence to deduce it, to reconstruct its genesis. But if power is in reality an open, more-or-less coordinated (in the event, no doubt, ill-coordinated) cluster of relations, then the only problem is to provide oneself with a grid of analysis which makes possible an analytic of relations of power. ${ }^{110}$

In comparison, Arendt's discussion of violence can be situated as an analytic of violence in place of a genealogy of a particular category of violence. Her ambition, Canovan explains, is not to say what one should be doing "but to distinguish this particular aspect of the human condition from the others." 111 Though both Arendt and Foucault attest to the non-teleological construction of our meaningful world and are interested in discerning hegemonic forms of power, Arendt was far more inclined to engage in the traditional notion of critique when differentiating concepts like violence, force, authoritarianism and democracy. While her accounts of power and vio-

\footnotetext{
${ }^{105}$ Foucault, "Confessions of the Flesh," 218.

106 Foucault, "Two Lectures," 24.

107 Arendt, Origins of Totalitarianism; Foucault, "Society Must Be Defended."

108 Foucault, "Two Lectures," 28

${ }^{109}$ Lynch, "Foucault's Theory," 15.

${ }^{110}$ My italics, Foucault, “Confessions of the Flesh," 199.

111 Canovan, Hannah Arendt, 130.
} 
lence become intertwined with her historical investigations in The Human Condition and The Origins of Totalitarianism, her adherence to the task of uncovering a definitive conceptual understanding of violence holds firm, aligning more with what Foucault meant by an analytic than by a genealogy. This conforms to her aforementioned pursuance of trans-historical conditions of human existence rather than contingent, historically-situated experiences. There can only be one analytic of power (open to contestation) since it is dealing with the existential conditions of power as a relational occurrence; the number of genealogies of power, nonetheless, is infinite and concerned with dispositifs and categories of power. ${ }^{112}$ For instance, Foucault stated the following on the dispositif of sexuality: "A heterogeneous ensemble, one which was finally completely overlaid by the apparatus [dispositif] of sexuality which in turn at a certain moment produced as the keystone of its discourse and perhaps of its very functioning, the idea of sex." ${ }^{113}$ In fact, Foucault elicited various categories of power and the dispositif through which they were deployed, such as biopolitics (which included sexuality), disciplinary power, governmentality and pastoral power. Moreover, these different categories were not strictly partitioned but fluid, imbricated and context-dependent, morphing into or pushing away from one another; at times, the strategical substructures would even combine into a complementary force or come into an antagonistic relationship with one another.

Still, the genealogical method was never a goal in itself but indicated something else: freedom. Power relations are inherently "nonegalitarian" in that they imply the possibility to act in an unexpected manner, ${ }^{114}$ so "as soon as there is a power relation, there is a possibility of resistance. We can never be ensnared by power: we can always modify its grip in determinate conditions and according to a precise strategy." 115 Yet, certain factors typically inhibit such a catachresis. For instance, I can declare myself a cosmopolitan citizen of the world, yet a national passport is still required to travel internationally. Some notions are able to complicate these boundaries (e.g., stateless persons, refugees, asylum seekers), but the need to organize these divergent groups in some order reinforces the importance of nationality demarcation. When factors become so stringently hegemonic, it is a state of domination, which Foucault explicitly relates to power:

One sometimes encounters what may be called situations or states of domination in which the power relations, instead of being mobile, allowing the various participants to adopt strategies modifying them, remain blocked, frozen...one is faced with what may be called a state of domination. ${ }^{116}$

\footnotetext{
112 This is not to argue that Arendt's oeuvre should be read as a unitary theory, which it most certainly should not due to her desire to explore various issues without having to rely on a larger theory of philosophy; however, she is more concerned with exploring the condition in which subjects exist.

${ }^{113}$ Foucault, "Confessions of the Flesh," 210.

${ }^{114}$ Foucault, History of Sexuality, 94.

115 Foucault, "Power and Sex," 123.

${ }^{116}$ Foucault, "Ethics of the Concern of the Self," 283.
} 
Through genealogies, domineering hegemonies are not dismantled but uncovered in the Heideggerian sense. It should still be noted that what is "uncovered" is not hermeneutic but a historical construction, one that helps us gain perspective on our historical and political situatedness, "a certain point of view which can be very useful as a tool for analyzing what's going on now - and to change it." 117

What is more, genealogies can uncover capabilities just as much as they can states of domination. Though a genealogy of race reveals how individuals are subjected as racial subjects, it simultaneously illustrates minority rights based on race and the racial identification required for solidarity movements. The dubiousness of Foucauldian domination, nevertheless, is its theoretical ambiguity. Strongly attached to freedom and resistance such that "there is no power without potential refusal or revolt," how one goes about analyzing domination is discussed much less by Foucault. ${ }^{118}$ Domination appears in the form of schools, sexual norms and neoliberalism, yet Jon Simons notes that Foucault fails to properly differentiate between power and domination, ${ }^{119}$ and even Foucault himself noted the lack of clarity on this point: "Here we are at the centre of the problem, and no doubt also of the obscurities of my own discourse." 120 This problematic impasse provides the potential to transpose Arendt's analytic of violence into Foucault's larger philosophy to make sense of domination. Domination would be the circumstances by which violence has intensified so much, meaning the potential to act otherwise has been limited to such an extent, that the exercise of freedom becomes extremely difficult (though not completely impossible). In Foucault's own words, states of domination occur when "an individual or social group succeeds in blocking a field of power relations" to the point where "practices of freedom do not exist or exist only unilaterally or are extremely constrained and limited"; in this way, violence does not target bodies or things but rather potentiality. ${ }^{121}$ Thus, domination is a way of discussing a strong degree of violence that heavily prevents spontaneity similar to Arendt's account of Terror.

Violence can be seen as relational and strategic, just as Arendt originally understood it, but its effects - the non-sovereign aspect of action - would allow systems of violence to calcify, which corresponds to the Foucauldian dispositif. A researcher could investigate the productive side (what is being produced via power) or the preventive side (what possibilities are being foreclosed through violence). This preventive dimension should not be reduced to a Foucauldian model of "juridical power" that only has the capacity to say "No," but instead an active component that takes advantage of what is in its environment to ensure the failure of competing strategies. Thus, this would not diminish Arendt and Foucault's rejection of traditional frameworks of power since vio-

\footnotetext{
117 Michel Foucault, “On the Genealogy of Ethics: An Overview of Work in Progress," in Michel Foucault: Beyond Structuralism and Hermeneutics (1982), 236.

118 Michel Foucault, “'Omnes et Singulatim': Toward a Critique of Political Reason” [1979], in The Essential Foucault: Selections From Essential Works of Foucault, 1954-1984, ed. Paul Rabinow and Nikolas Rose (2003), 201.

119 Simons, Foucault and the Political, 83.

${ }^{120}$ Foucault, "Confessions of the Flesh," 203.

${ }^{121}$ Foucault, "Ethics of the Concern for Self," 283.
} 
lence does not repress but poses the intent to prevent. For instance, ghettoization in the U.S. is not imposed through force (though it may have been in the past) but through a series of produced political, social and economic mechanisms that have institutionally segregated living spaces. While it has been produced, which is power, it also prevents, which is violence. The discrimination and racism faced in wealthier communities as well as the inequitable distribution of wealth between races contributes to this. The tactic of genealogies hence becomes a potential strategy for uncovering the historical formation of violence as well: "[To] see how these mechanisms of power [or violence] have been and continue to be - invested, colonized, utilized, involuted, transformed, displaced, extended, etc., by ever more general mechanisms and by forms of global domination." 122 What this calls for is not simply a discovery of violent acts, meaning their method, but a genealogical investigation into categories of violence, or their function.

It consequently becomes of principal importance to fathom the rationalization behind violence, which parallels the claim made by Oksala such that "we have to understand the specific and distinct rationality that practices of violence attain in different power networks in order to effectively criticize them." ${ }^{123}$ However, she limits her analysis to physical forms of violence. ${ }^{24}$ Instead of viewing violence in terms of physical acts, its terminus, one must investigate and seek out the rationalizations, or categories, that are the driving force behind violence: "The analysis, made in terms of power [or violence], must not assume that the sovereignty of the state, the form of the law, or the over-all unity of a domination are given at the outset; rather, these are only the terminal forms power takes." ${ }^{125}$ For this reason, Arendt's critique (analytic) of violence becomes necessary to build upon to uncover specific, historically implemented (categories of) violence: "To use [force, power, strength and violence] as synonyms not only indicates a certain deafness to linguistic meanings, which would be serious enough, but it has also resulted in a kind of blindness to the realities they correspond to." 126 This approach would not only separate power and violence but concurrently permit a more in-depth debate on specific issues, especially considering that violent acts are categorized not by their content but by their justification. For instance, instead of comparing racial assaults to other assaults, one could link it to other forms of racial violence to understand its limits or triggers.

If new forms of power are generative, then old force relations are necessarily being cut off/prevented. Change implies violence just as much as power, but this need not involve physical altercations. Perhaps the most violent act would be the destruction of a paradigm. One could read Arendt's discussion of revolutions and Foucault's comments on fascism in this regard. The French Revolution was the prevention of a social and political hierarchy just as the American Civil Rights Movement aimed at the prevention (or rather abolishment) of a racially-segregated system. Such a reading further reinforces

\footnotetext{
${ }^{122}$ Foucault, “Two Lectures," 37.

${ }^{123}$ Oksala, Foucault, Politics, and Violence, 9.

124 Ibid., 8-9.

${ }^{125}$ Foucault, History of Sexuality, 92.

${ }^{126}$ Arendt, On Violence, 43.
} 
the conceptual gap between violence and "juridical" or "traditional" models of power, ensuring they are not reduced to one another. In light of this conclusion, resistance can be seen as the mode of the practice of freedom: "More often one is dealing with mobile and transitory points of resistance, producing cleavages in a society that shift about, fracturing unities and effecting regroupings." ${ }^{127}$ This returns us, however, to the question of whether violence can be seen as good or bad. Considering the fact that Foucault wishes to avoid normative claims altogether and Arendt's cryptic and opaque conclusions cause difficulty in asserting normative claims, how do we understand violence?

This predicament is resolvable by distinguishing first-order from second-order normative claims. First-order normative claims detail the (un)acceptability of particular actions. For instance, understanding murder and graffiti as wrong in-themselves would be in this category. For second-order claims, the foundation of the act is what is significant, and both Arendt and Foucault, whether directly or indirectly, make a second-order claim that freedom is desirable. Foucault understands this as the attitude of the Enlightenment that seeks to both understand what we are and test the ability to go beyond that through critique: "The critique of what we are is at one and the same time the historical analysis of the limits imposed on us and an experiment with the possibility of going beyond them." ${ }^{128}$ In a unique display of these sorts of normative claims, Foucault asserts that he is in favor of freedom of "choice" rather than freedom of "acts," arguing rape should not be included in the fight for sexual rights, which is a strong rebuttal against critics who argue that Foucault's non-normative framework prevents one from making any worthwhile judgments. ${ }^{22}$ For Arendt, freedom is the human condition, and to remove that condition would be to cease being human. Thus, "Without a politically guaranteed public realm, freedom lacks the worldly space to make its appearance. [...] Freedom as a demonstrable fact and politics coincide and are related to each other like two sides of the same matter." ${ }^{130}$ As freedom is engrained in power and power is the source of meaning, to remove it would be to make the world unintelligible.

Framing violence as such does not suddenly mean murder or terrorism will be able to adequately justify themselves on a second-order plane as they can extremely restrict, or entirely remove, the potential for spontaneity (as Foucault's comment on rape illustrates). However, this forces us to rethink the way we not only view violence but interact with others. Not injuring others would not be a sufficient cause to perform an action because you may be restricting freedom in a different respect. On the other hand, acts such as assassinations and terrorism would have to be looked at from a revised perspective. Oftentimes, someone's terrorist is another person's freedom fighter. When discussing the heritage of groups such as the Irish Republican Army or the Partiya Karkerên Kurdistanê (Kurdistan Workers' Party), one can most certainly find unjustified acts of bloodshed, but the larger effect of these movements paved the way for political parties

\footnotetext{
${ }^{127}$ Foucault, History of Sexuality, 96.

${ }^{128}$ Foucault, "What Is Enlightenment?," 56.

${ }_{129}$ Michel Foucault, "Sexual Choice, Sexual Act" [1983], in Essential Works of Foucault 1954-1984, Volume 1: Ethics, Subjectivity and Truth, ed. Paul Rabinow (1997), 143.

${ }^{130}$ Arendt, "What Is Freedom?," 442.
} 
like Sinn Fein and Halklarm Demokratik Partisi (People's Democratic Party). In that respect, these groups opened up far more areas for potential action and thought than would have been possible without them. This claim does not justify these acts or groups in any way but necessitates a new project that investigates them in greater depth and complexity. Moreover, these groups can easily be contrasted with groups like the Klu Klux Klan and Daesh (ISIS), which are largely built upon sustaining the ability to act for some based on the restriction of this right for others. Unlawful acts of civil disobedience combating systematic domination could be rethought and defended. While not an endall solution, this interpretation gives us a position to pragmatically assess systemic violence that often escapes detection while not disenfranchising resistant and politically charged acts that are often delegitimized by declarations of "violence" nor empower groups fundamentally rooted in tactics of permanently restricting the potential to act from segments of a population. More than anything, this allows us to reflexively contemplate and struggle against nexuses of power/violence that are near and dear to our daily lives, yet function on the prevention of an Other's potential.

\section{CONCLUSION}

Though often overlooked, Arendt and Foucault overlap on many levels, yet it is the high value they place on freedom that truly ties them together. Arendt's critique of violence is subsequently not too far-fetched to be subsumed under a Foucauldian structure. Seeing violence as the prevention or harm of potential, which is not always physical, makes sense in this respect. It is built on the Foucauldian intersubjective yet nonautonomous components of power and ends in the calcification of systems of violence, parallel to dispositifs, which are genealogically analyzable. Most importantly, violence depends on the productive aspect of power to function, as it exists through such rationalization. That violence is exercised within the conditions of possibility/state of appearance is paramount to understanding its preventive elements. Relying on a second-order normative claim allows Arendt and Foucault to bypass accusations of non-normative-based claims, primarily when it comes to the case of freedom.

In the process, Foucauldian violence opens up prosperous ways to explore domination/resistance, potentiality and subjectivity. It makes domination less ambiguous and allows it to be directly mapped out. Nonetheless, this approach would still need to bypass the limitations given by Oksala in the introduction, according to which my broad understanding of violence would (1) inhibit scholarly analysis, (2) illegitimize certain acts of protest or (un)civil disobedience and (3) make violence intrinsic to politics. As I hope is clear by now, I do not aim at making violence incomprehensible but rather wish to rethink how it is perpetrated, which in no way restricts academics from looking at specific forms of violence or the manner in which they are exercised (e.g., assault, protest, rape, torture, etc.). Instead, I situate these traditionally-deemed physical acts as the terminal points of violence, requiring a theoretical step back to encapsulate and explore the processes of rationalization behind them. Like Oksala, I argue that categories of vio- 
lence are contingent and historically constructed, so to equate domestic violence in a Spanish household and an Egyptian household would not make sense if the rationalization behind the acts varied. This is particularly useful for double-excluded minorities like homosexuals or women within a minority. In the same vein, and in response to (2), it would not make certain forms of violence related to protest or (un)civil disobedience illegitimate or uncontested but problematize the legitimacy of conventionally accepted forms of violence like state terrorism or institutional violence.

The final point is a little more complex, and to answer it we must understand why Oksala has put forward this particular feature. According to her, making violence intrinsic to politics, or power, would simultaneously mean it is ineradicable, which risks justifying violence itself: "It is my contention that while the 'violence of language' is precisely ontological in the sense of being a necessary feature of thought, physical violence is contingent, historically specific, and context-dependent." ${ }^{131}$ Yet, this is not contradictory with my framework. I could easily see a situation where Oksala's physical violence is eliminated-and Oksala sees this as an ideal rather than as a pragmatic goal-yet violence (prevention of potential) still remains and work is still to be done. Thus, if violence is not being physically perpetrated - if we granted a certain domain as "physical acts" where has it shifted to? In what ways is freedom being sealed off, prevented and overdetermined?

\section{References}

Allen, Amy, "Power, Subjectivity, and Agency: Between Arendt and Foucault," International $\begin{array}{lllll}\text { Journal of Philosophical } & \text { Studies } & 10: 2 & \text { (2002), } & \text { 131-49. }\end{array}$ https://doi.org/10.1080/09672550210121432.

Arendt, Hannah, The Human Condition [1958]. Chicago and London: The University of Chicago Press, 1998.

Arendt, Hannah, “The Jewish War That Isn't Happening: Articles from Aufbau, October 1941-November 1943," in The Jewish Writings, ed. Jerome Kohn and Ron H. Feldman, 134185. New York: Schocken Books, 2007.

Arendt, Hannah, The Life of the Mind [1971]. San Diego, New York and London: Harcourt Inc., 1978.

Arendt, Hannah, On Violence. San Diego, New York and London: Harcourt Brace Jonanovich, 1969.

Arendt, Hannah, The Origins of Totalitarianism [1951]. San Diego, New York and London: Harcourt Brace \& Company, 1979.

Arendt, Hannah, "Truth and Politics" [1967], in The Portable Hannah Arendt, ed. Peter Baehr, 545-575. New York: Penguin Putnam Inc., 2000.

Arendt, Hannah, "What Is Freedom?" [1961] in The Portable Hannah Arendt, ed. Peter Baehr, 438-461. New York and London: Penguin Books, 2000.

${ }^{131}$ Oksala, Foucault, Politics, and Violence, 37. 
Avelar, Idelber, The Letter of Violence: Essays on Narrative, Ethics, and Politics. New York and Houndmills: Palgrave Macmillan, 2004.

Baudrillard, Jean, Forget Foucault [1977]. Los Angeles: Semiotext(e), 2007.

Benhabib, Seyla, "Hannah Arendt and the Redemptive Power of Narrative," in Hannah Arendt: Critical Essays, ed. Lewis P. Hinchman and Sandra K. Hinchman, 111-137. Albany, NY: State University of New York Press, 1994.

Canovan, Margaret, Hannah Arendt: A Reinterpretation of Her Political Thought Cambridge and New York: Cambridge University Press, 1992.

Dillon, Michael and Andrew W. Neal, eds., Foucault on Politics, Security and War. London and New York: Palgrave Macmillan, 2008.

Dolan, Frederick M, "The Paradoxical Liberty of Bio-Power: Hannah Arendt and Michel Foucault on Modern Politics," Philosophy \& Social Criticism 31:3 (2005), 369-80. https://doi.org/10.1177/0191453705051710

Michel Foucault, The Archeology of Knowledge and The Discourse on Language [1969]. London and New York: Vintage Books, 2010.

Foucault, Michel, "Body/Power" [1975], in Power/Knowledge: Selected Interviews and Other Writings, 1972-1977, ed. Colin Gordon, 55-62. New York: Pantheon Books, 1980.

Foucault, Michel, “Confessions of the Flesh" [1977], in Power/Knowledge: Selected Interviews \& Other Writings 1972-77, ed. Colin Gordon, 194-228. New York: Pantheon Books, 1980.

Foucault, Michel, Discipline \& Punish: The Birth of the Prison [1975]. New York: Vintage Books, 1995.

Foucault, Michel, "The Ethics of the Concern for Self as a Practice of Freedom" [1984], in Essential Works of Foucault 1954-1984, Volume 1: Ethics, Subjectivity and Truth, ed. Paul Rabinow, 281-302. New York: The New Press, 1997.

Foucault, Michel, The History of Sexuality, Vol. 1: An Introduction [1976]. New York: Vintage Books, 1990.

Foucault, Michel, "The History of Sexuality" [1977], in Power/Knowledge: Selected Interviews and Other Writings, 1972-1977, ed. Colin Gordon, 183-193. New York: Pantheon Books, 1980.

Foucault, Michel, "Nietzsche, Genealogy, History" [1971], in The Essential Foucault: Selections From Essential Works of Foucault, 1954-1984, ed. Paul Rabinow and Nikolas Rose, 351-369. New York: The New Press, 2003.

Foucault, Michel, “'Omnes et Singulatim': Toward a Critique of Political Reason” [1979], in The Essential Foucault: Selections From Essential Works of Foucault, 1954-1984, ed. Paul Rabinow and Nikolas Rose, 180-201. New York: The New Press, 2003.

Foucault, Michel, "On the Genealogy of Ethics: An Overview of Work in Progress," in Michel Foucault: Beyond Structuralism and Hermeneutics, 229-252. Chicago: The University of Chicago Press, 1982.

Foucault, Michel, "Power and Sex" [1977], in Michel Foucault: Politics, Philosophy, Culture, Interviews and Other Writings 1977-1984, ed. Lawrence D. Kritzman, 110-124. New York: Routledge, 1990. 
Foucault, Michel, "Sexual Choice, Sexual Act" [1983], in Essential Works of Foucault 1954-1984, Volume 1: Ethics, Subjectivity and Truth, ed. Paul Rabinow, 141-156. New York: The New Press, 1997.

Foucault, Michel, "Society Must Be Defended": Lectures at the Collège de France, 1975-1976 [1997]. New York: Picador, 2003.

Foucault, Michel, "The Subject and Power," in Michel Foucault: Beyond Structuralism and Hermeneutics, 208-228. Chicago: The University of Chicago Press, 1982.

Foucault, Michel, "Two Lectures" [1976], in Critique and Power: Recasting the Foucault/Habermas Debate, ed. Michael Kelly, 17-46. Cambridge and London: MIT Press, 1994.

Foucault, Michel, "What is Called 'Punishing? [1984],'” in Essential Works of Foucault 19541984, Volume 3: Power, ed. James D. Faubion, 382-393. New York: The New Press, 2001.

Foucault, Michel, "What Is Enlightenment?" [1984], in The Essential Foucault: Selections From Essential Works of Foucault, 1954-1984, ed. Paul Rabinow and Nikolas Rose, 43-57. New York: The New Press, 2003.

Franěk, Jakub, "Arendt and Foucault on Power, Resistance, and Critique," Acta Politologica 6:3 (2014): 294-309.

Fraser, Nancy, "Michel Foucault: A 'Young Conservative?'” [1985\}, in Critique and Power: Recasting the Foucault/Habermas Debate, ed. Michael Kelly, 185-210. Cambridge and London: The MIT Press, 1994.

Frazer, Elizabeth and Kimberly Hutchings, "Avowing Violence: Foucault and Derrida on Politics, Discourse and Meaning," Philosophy \& Social Criticism 37:1 (2011): 3-23. https:/ / doi.org/10.1177/0191453710384359.

Fry, Karin A., Arendt: A Guide for the Perplexed. London and New York: Continuum International, 2009.

Gros, Frédéric, “Foucault, Penseur de la Violence?," Cités 50 (2012), 75-86. https: / / doi.org/10.3917/ cite.050.0075.

Habermas, Jürgen, “Hannah Arendt's Communications Concept of Power" [1977], in Hannah Arendt: Critical Essays, ed. Lewis P. Hinchman and Sandra K. Hinchman, 211-230. Albany, NY: State University of New York Press, 1994.

Habermas, Jürgen, The Philosophical Discourse of Modernity: Twelve Lectures [1985]. Cambridge and Maldon, MA: The MIT Press, 1990.

Kelly, Mark G. E., The Political Philosophy of Michel Foucault. New York and London: Routledge, 2012.

Lynch, Richard, "Foucault's Theory of Power," in Michel Foucault: Key Concepts, ed. Dianna Taylor, 13-26. Durham, NC: Acumen, 2011.

Milchman, Alan and Alan Rosenberg (ed.), Foucault and Heidegger: Critical Encounters. Minneapolis and London: University of Minnesota Press, 2003.

Moi, Toril, "Power, Sex and Subjectivity: Feminist Reflections on Foucault," Paragraph 5 (1985), 95-102. https:/ / doi.org/10.3366/ para.1985.0007

O'Farrell, Clare, Michel Foucault. London, Thousand Oaks, CA and New Delhi: Sage Publications Ltd., 2005. 
Oksala, Johanna, Foucault, Politics, and Violence. Evanston, IL: Northwestern University Press, 2012.

Penta, Leo J., "Hannah Arendt: On Power,” The Journal of Speculative Philosophy 10:3 (1996), 210-229.

Simons, Jonathan, Foucault and the Political. London and New York: Routledge, 1995.

Villa, Dana R., Arendt and Heidegger: The Fate of the Political. Princeton: Princeton University Press, 1996.

Villa, Dana R., "Postmodernism and the Public Sphere," The American Political Science Review 86:3 (1992), 712-21. https:/ / doi.org/10.2307/1964133

\title{
Acknowledgement
}

I would like to thank Jakub Franěk for his comments on an early draft of this article as well as the two reviewers whose comments helped bring it into its final version.

FUNDING: This article was written within a Specific Academic Research project of the Institute of Political Science, Charles University, Prague, no. 260 461/2017 Interests, Power and Institutions in Political Decision Making as well as the Charles University Grant Agency, no. 494217 Nationalist Violence and Identity in France and Turkey.

\author{
Author info \\ Jacob Maze \\ PhD Student \\ Department of Political Science \\ Charles University \\ Czech Republic \\ Jacob.maze@fsv.cuni.cz
}

Jacob Maze is a PhD student at the Department of Political Science, Faculty of Social Sciences, Charles University (Prague, Czech Republic) and editor of Journal of Nationalism, Memory $\mathcal{E}$ Language Politics. His research focuses on the issues of Michel Foucault, Hannah Arendt, political violence, nationalism (particularly in France and Turkey) and identity politics. He completed his masters at the Department of Philosophy, Middle East Technical University (Ankara, Turkey). He is currently involved in the research project Beyond Hegemonic Narratives and Myths: Troubled Pasts in the History and Memory of East-Central \& South-East Europe (PRIMUS, Charles University), Nationalist Violence and Identity in France and Turkey (GA UK, Charles University) and Transformation of the Islamist Parties: Findings from Turkey (GA CR, Anglo American University). 